\title{
Marian Visionaries of Medjugorje
}

To the Editor:

Craig Lundahl's article "A Comparison of Other World Perceptions by Near-Death Experiencers and by the Marian Visionaries of Medjugorje" in the Fall 2000 issue of the Journal contained a geographical mistake. The author located Medjugorje in Croatia, which is not the case. Medjugorje is in the former Yugoslav republic of Bosnia and Herzegovina. This former Yugoslav republic is now, after a bloody civil war, an independent state with the same name. Bosnia and Herzegovina was and is a multi-ethnic state. Medjugorje is located in the part of Bosnia and Herzegovina called West Herzegovina. However, the majority of the population in Medjugorje are Croats.

\section{Reference}

Lundahl, C. R. (2000). A comparison of other world perceptions by near-death experiencers and by the Marian visionaries of Medjugorje. Journal of Near-Death Studies, $19,45-52$.

Bogomir Golobič

IANDS Slovenia

Mestne Njive 10

8000 Novo Mesto

Slovenia

e-mail: bogomir.golobic@krka.si 